\title{
Estimation of feed intake by cattle using controlled-release capsules containing n-alkanes or chromium sesquioxide
}

\author{
L. M. M. FERREIRA ${ }^{1 *}$, M. OLIVÁN ${ }^{2}$, M. A. M. RODRIGUES ${ }^{1}$, K. OSORO $^{2}$, \\ H. DOVE ${ }^{3}$ AND A. DI AS-DA-SILVA ${ }^{1}$ \\ ${ }^{1}$ CECAV - Departamento de Zootecnia, Universidade de Trás-os-Montes e Alto Douro, Apartado 1013, \\ 5001 Vila Real Codex, Portugal \\ ${ }^{2}$ SERIDA - Servicio Regional de Investigación y Desarrollo Agroalimentario, Apartado 13, \\ 33300 Villaviciosa, Asturias, Spain \\ ${ }^{3}$ CSIRO Plant Industry, GPO Box 1600, Canberra, ACT 2601, Australia
}

(Revised MS received 12 March 2004)

\begin{abstract}
SUMMARY
An experiment was carried out to evaluate the utilization of the n-alkane technique and the chromium sesquioxide $\left(\mathrm{Cr}_{2} \mathrm{O}_{3}\right)$ /acid insoluble ash (AIA) procedure to estimate feed intake of meadow hay by two breeds of cattle. The animals were housed in individual pens, and offered known amounts of meadow hay as the sole diet component. One group of 4 Barrosã cows (average weight, $457 \pm 24 \mathrm{~kg}$ ) and another group of 4 Holstein-Friesian cows (average weight, $635 \pm 148 \mathrm{~kg}$ ) were dosed with intraruminal controlled-release capsules (CRC) that contained alkane markers or $\mathrm{Cr}_{2} \mathrm{O}_{3}$ in separate capsules. During intake estimation, meadow hay and faeces were sampled twice daily. There was no significant effect of grab sampling time on the meadow hay intake estimation, due to the fact that no differences were observed in the faecal marker concentrations.

The mean real intakes, measured as the difference between the dry weight of feed offered each day and the dry weight of daily feed refusal, were 5.64 and $7.76 \mathrm{~kg} \mathrm{DM} /$ day for Barrosã and HolsteinFriesian cows, respectively. For Barrosã cows the mean estimated intakes when using the CRC release rates documented by the manufacturer (MRR) were $5 \cdot 66,6 \cdot 59$ and $6.90 \mathrm{~kg} \mathrm{DM} / \mathrm{day}$, using the $\mathrm{Cr}_{2} \mathrm{O}_{3}$ /AIA procedure, $\mathrm{C}_{31}: \mathrm{C}_{32}$ and $\mathrm{C}_{33}: \mathrm{C}_{32}$ n-alkane pairs, respectively. For Holstein-Friesian cows the same markers gave values of $7 \cdot 72,8.51$ and $8.95 \mathrm{~kg} \mathrm{DM} /$ day, respectively. Mean daily intake estimation was improved when the release rate calculated as the reduction rate in CRCs payload performed in a additional experiment (CRR), was used. The differences from the real intake values, obtained using $C_{31}: C_{32}$ and $C_{33}: C_{32}$ alkane pairs, decreased from 950 and $1260 \mathrm{~g} /$ day to 140 and $420 \mathrm{~g} /$ day, respectively, for Barrosã cows and from 750 and $1190 \mathrm{~g} /$ day to 290 and $90 \mathrm{~g} /$ day for Holstein-Friesian cows. The intake estimation using the $\mathrm{Cr}_{2} \mathrm{O}_{3} / \mathrm{AIA}$ procedure was not affected by correcting the CRC release rate, because the release rates of both MRR and the CRR were similar.

The results indicate that controlled-release capsules provide a uniform marker release in cattle, but also suggest that to obtain accurate estimates of intake, it is better to measure release rates within the context of particular experiments.
\end{abstract}

\section{INTRODUCTION}

An estimate of dry matter intake is an essential component of the evaluation of the nutritive value of feed and the nutritional status of the animal, and therefore

* To whom all correspondence should be addressed. Email: $\operatorname{lmf}(a$ utad.pt the performance of animal production systems. As direct measurements of individual intakes are difficult to obtain using group-housed and grazing animals, the search for methodologies to estimate voluntary intake has led to the development of techniques relying on the use of indigestible markers to estimate faecal excretion and digestibility (Burns et al. 1994). 
The most extensively studied markers are lignin (Van Soest 1994) and acid insoluble ash (AIA; Block et al. 1981; Sunvold \& Cochran 1991) as internal markers to estimate digestibility, and chromium sesquioxide $\left(\mathrm{Cr}_{2} \mathrm{O}_{3}\right.$; Parker et al. 1990; Luginbuhl et al. 1994) as an external marker to estimate faecal output. An alternative methodology is the n-alkane technique, based on the relation between odd-chain alkanes, naturally present in epicuticular waxes of plants, and even-chain alkanes given in daily doses either through paper pellets (Mayes et al. 1986), gelatine capsules (Dove et al.2000) or through the use of controlled-release devices (Berry et al. 2000; Dove et al. 2002).

The use of any of these markers presents similar problems, such as obtaining representative samples due to high heterogeneity in plants and faeces, diurnal variation of excretion of marker and analytical problems related to the extraction methodologies.

The aim of the current study was to compare the use of the $\mathrm{Cr}_{2} \mathrm{O}_{3} / \mathrm{AIA}$ procedure and the n-alkane pairs $\mathrm{C}_{31}: \mathrm{C}_{32}$ and $\mathrm{C}_{33}: \mathrm{C}_{32}$ to estimate forage intake of housed cattle. The effectiveness of controlled-release capsules containing $\mathrm{Cr}_{2} \mathrm{O}_{3}$ or alkanes $\left(\mathrm{C}_{32}\right.$ and $\left.\mathrm{C}_{36}\right)$ as marker delivery devices was evaluated. We also examined the influence of grab-sampling time on the accuracy of intake estimates.

\section{MATERIALS AND METHODS}

\section{Animals and diets}

Eight non-lactating cows, comprising four Holstein-Friesian cows (live weight, $635 \pm 148 \mathrm{~kg}$ ) and four cows of the indigenous Barrosã breed (live weight, $457 \pm 24 \mathrm{~kg}$ ), were housed in individual rubber-floored stalls designed for digestibility trials. The purpose of using two cattle breeds was to test the use of the intra-ruminal controlled-release capsules (CRCs), developed for adult cattle of a wide range of live weights, in two breeds of different adult size.

The diet used in this experiment consisted of chopped meadow hay, supplied in individual mangers in order to measure individual intakes. The chemical composition of the meadow hay is presented in Table 1. The main plant species present in the meadow hay were Lolium perenne, Holcus lanatus and Bromus sp. The animals were fed close to the maintenance feeding level (AFRC 1993); half the daily ration was fed at $08.00 \mathrm{~h}$ and half at $20.00 \mathrm{~h}$, in an attempt to prevent selection within the hay. All animals had free access to water and mineral blocks.

\section{Experimental procedure}

The experimental work consisted of a preliminary period of 15 days for adaptation of the animals to the diet and experimental conditions, and 7 days for the collection of representative samples of meadow hay,
Table 1. Chemical composition of the meadow hay ${ }^{\text {a }}$

\begin{tabular}{lcc}
\hline \hline $\begin{array}{l}\text { Chemical composition } \\
(\mathrm{g} / \mathrm{kg} \mathrm{DM})\end{array}$ & Mean & \\
\hline Organic matter & 931 & $0 \cdot 8$ \\
Crude protein $(\mathrm{N} \times 6 \cdot 25)$ & 72 & $1 \cdot 0$ \\
Neutral detergent fibre & 641 & $5 \cdot 6$ \\
Acid detergent fibre & 409 & $3 \cdot 0$ \\
Acid detergent lignin & 56 & $1 \cdot 5$ \\
Cellulose & 354 & $2 \cdot 8$ \\
Hemicellulose & 243 & $5 \cdot 6$ \\
\hline
\end{tabular}

a Each value is the mean of 14 samples.

${ }^{\mathrm{b}}$ NDF ash free, assayed without sodium sulphite.

S.E.M. standard error of mean.

refusals and faeces. Refusals as well as two samples of meadow hay were collected before each feeding.

The external markers $\left(\mathrm{Cr}_{2} \mathrm{O}_{3}\right.$ and the alkanes ndotriacontane, $\mathrm{C}_{32}$, and n-hexatriacontane, $\mathrm{C}_{36}$ ), were administered using intra-ruminal controlled-release capsules (CRC, type MCM, Captec Ltd, Auckland, New Zealand) designed for $300-650 \mathrm{~kg}$ live weight cattle. The expected mean release rates of alkanes documented by the company were 317.2 and $335.4 \mathrm{mg} /$ day for $\mathrm{C}_{32}$ and $\mathrm{C}_{36}$ respectively. For the chromium, the documented mean release rate was $1.43 \mathrm{~g}$ of $\mathrm{Cr}_{2} \mathrm{O}_{3} /$ day, corresponding to $978.4 \mathrm{mg} \mathrm{Cr} /$ day.

An alkane and a $\mathrm{Cr}_{2} \mathrm{O}_{3} \mathrm{CRC}$ were inserted intraruminally in the second week of the adaptation period, using a length of rubberized tubing and plunger specifically designed to match capsule diameter. The faecal collection period lasted 7 days from days 15 to 22. The samples were collected through grab sampling at the time of feeding $(08.00 \mathrm{~h}, 20.00 \mathrm{~h})$. As the high fibre content of the feed was expected to induce longer retention times in the rumen (Van Soest 1994) a peak passage delay of $48 \mathrm{~h}$ was assumed. Thus, measured intakes represent data from days 13-20 and recoveries of alkanes and chromium were calculated from sampling days 15-22.

Samples from the meadow hay, refusals and faeces were immediately dried on the day of collection, using an forced-air oven at $60^{\circ} \mathrm{C}$ for $72 \mathrm{~h}$, and milled through a $1 \mathrm{~mm}$ screen. The samples destined for alkane analyses were immediately frozen at $-20 \mathrm{C}$, freeze-dried, and milled through a $1 \mathrm{~mm}$ screen.

\section{Analysis of marker content and release rate of $C R C S$}

In order to calculate the release rate (CRR) of n-alkanes and $\mathrm{Cr}_{2} \mathrm{O}_{3}$ from the $\mathrm{CRCs}$, as distinct from the manufacturer's stated release rates (MRR), three non-lactating cows (one Holstein-Friesian cow (live weight, $650 \mathrm{~kg}$ ) and two cows of the indigenous Barrosã breed (live weight, $473 \pm 8 \mathrm{~kg}$ )) with 
permanent rumen fistulae fitted with cannulae were used in an additional experiment. The experimental procedures used were the same as described for the intake estimation experiment.

One $\mathrm{Cr}_{2} \mathrm{O}_{3} \mathrm{CRC}$ and one alkane $\mathrm{CRC}$ were inserted into the rumen of each cow via the fistula and were suspended from the cannula plug by a nylon cord of sufficient length to permit movement of the device around the rumen. Before CRCs were inserted, the length of active core was measured using callipers, at 4 equidistant points around the circumference of the CRCs (Dove et al. 2002).

On day 2 after CRC administration, the $\mathrm{Cr}_{2} \mathrm{O}_{3}$ and alkane CRCs were removed from the rumen and the length of the active core was measured again. The time of day was recorded, to allow active core length to be related to elapsed time, and the devices then returned carefully to the rumen. This procedure continued every second day up to and including day 18 after administration.

The daily release rates (mm/day) of $\mathrm{Cr}_{2} \mathrm{O}_{3}$ and alkanes $\mathrm{C}_{32}$ and $\mathrm{C}_{36}$ from the CRCs were estimated as the slope of the linear regression of payload length v. elapsed time, and were converted to $\mathrm{mg}$ of $\mathrm{Cr}_{2} \mathrm{O}_{3}$, $\mathrm{C}_{32}$ and $\mathrm{C}_{36}$ per day from the analyses of $\mathrm{Cr}_{2} \mathrm{O}_{3}$ and alkane content in $\mathrm{mg} / \mathrm{mm}$ payload, as indicated by the manufacturer $\left(141.7 \mathrm{mg}\right.$ of $\mathrm{C}_{32} / \mathrm{mm}, 149.86 \mathrm{mg}$ of $\mathrm{C}_{36} / \mathrm{mm}$ and $1009 \mathrm{mg}$ of $\mathrm{Cr}_{2} \mathrm{O}_{3} / \mathrm{mm}$, corresponding to $690.36 \mathrm{mg}$ of $\mathrm{Cr} / \mathrm{mm}$ ).

\section{Chemical analysis}

\section{Alkane analysis}

Alkane content of individual samples of meadow hay, refusals and faeces (morning and evening samples) were analysed in duplicate by direct saponification according to the methods of Mayes et al. (1986) and Oliván \& Osoro (1994) with minor modifications. The first stage involved a saponification of $0.5 \mathrm{~g}$ of faeces or $1.5 \mathrm{~g}$ hay for $14 \mathrm{~h}$ in $7 \mathrm{ml}$ ethanolic $\mathrm{KOH} 1 \mathrm{M}$ at $90^{\circ} \mathrm{C}$ in a dry-block heater (Techne DB-3, Techne Ltd., Duxford, Cambridge, UK). Afterwards, a hot extraction was performed with $\mathrm{n}$-heptane at $65^{\circ} \mathrm{C}$ (Oliván \& Osoro 1999). After the extraction, the sample was passed through a silica-gel column (bed volume $5 \mathrm{ml}$ ), to separate the alkanes from pigments, sterols and alcohols. Samples eluted from the columns were evaporated to dryness, then redissolved in $500 \mu \mathrm{l}$ heptane for chromatographic analysis. Quantification of the alkanes was carried out by gas chromatography, using a VARIAN 3400 GC, equipped with flame ionization detector (FID), an 8200 autosampler and a temperature-programmable injector. Alkane extracts were injected $(0 \cdot 5 \mu \mathrm{l})$ by on-column injection on a 15-metre column DB-1 megabore of $0.530 \mathrm{~mm}$ internal diameter and $1.5 \mu \mathrm{m}$ film thickness. Helium was used as a carrier gas at a constant flow of $15 \mathrm{ml} / \mathrm{min}$. Gradients of temperature were used for the injector $\left(80^{\circ} \mathrm{C}\right.$ for $0.2 \mathrm{~min} ; 200 \mathrm{C} / \mathrm{min}$ to $380 \mathrm{C})$ and the column $\left(200 \mathrm{C}\right.$ for $1 \mathrm{~min} ; 6^{\circ} \mathrm{C} / \mathrm{min}$ to $300 \mathrm{C} ; 6 \mathrm{~min}$ at $300 \mathrm{C}$ ). The detector oven was maintained at $350 \mathrm{C}$.

Gas chromatographic method was calibrated with a standard solution containing a mixture of synthetic alkanes (from $\mathrm{C}_{23}$ to $\mathrm{C}_{36}$ ) with concentrations similar to those found in extracts. The response factors for individual alkanes were calculated from peak areas and the known concentrations. The detector response to varied concentrations of each solute was linear throughout the range of concentrations found in the injected samples. Alkane concentrations were quantified relative to known amounts of the internal standards $\mathrm{C}_{22}$ (n-docosane) and $\mathrm{C}_{34}$ (n-tetratriacontane), added at the beginning of the extraction process. The use of two internal standards enabled the evaluation of the effectiveness of the extraction process and the correction of the peak areas for any discrimination detected during the solvent-extraction step (Oliván \& Osoro 1999).

\section{Other analyses}

Ash and nitrogen were analysed following the procedures of the Association of Official Analytical Chemists (AOAC 1990). Neutral detergent fibre (NDF), acid detergent fibre (ADF) and acid detergent lignin (ADL) were analysed by the method of Robertson and Van Soest (1981). Hemicellulose and cellulose were calculated as the difference between NDF and $\mathrm{ADF}$ and $\mathrm{ADF}$ and $\mathrm{ADL}$, respectively. Concentration of $\mathrm{Cr}_{2} \mathrm{O}_{3}$ was determined by atomic absorption spectrometry according to Fenton \& Fenton (1979). Determination of acid insoluble ash (AIA) was performed using the method of Van Keulen \& Young (1977).

\section{Calculations}

The concentrations of naturally occurring $C_{31}$ and $C_{33}$ and dosed $\left(\mathrm{C}_{32}\right)$ n-alkanes in both meadow hay and faeces samples were used to calculate meadow hay intake according to the equation proposed by Mayes et al. (1986) and expressed below in a simplified version:

Meadow hay intake $(\mathrm{kg} \mathrm{DM} / \mathrm{day})=\frac{D_{j}}{\frac{F_{j}}{F_{i}} * H_{i}-H_{j}}$

where $D_{j}$ is the release rate of the CRC for $\mathrm{C}_{32}(\mathrm{mg} /$ day), $F_{i}$ and $H_{i}$ are the respective concentrations ( $\mathrm{mg} / \mathrm{kg} \mathrm{DM}$ ) of $\mathrm{C}_{31}$ or $\mathrm{C}_{33}$ in faeces and meadow hay and $F_{j}$ and $H_{j}$ are the respective concentrations $(\mathrm{mg} / \mathrm{kg} \mathrm{DM})$ of $\mathrm{C}_{32}$ in faeces and meadow hay.

The meadow hay intake was also estimated from the $\mathrm{Cr}_{2} \mathrm{O}_{3} / \mathrm{AIA}$ procedure using the formula :

Meadow hay intake $(\mathrm{kg} \mathrm{DM} /$ day $)=\frac{\text { Faecal output }}{1-\text { Digestibility }}$ 
Faecal output was calculated in turn from the equation:

$$
\text { Faecal output }(\mathrm{kg} / \text { day })=\frac{D_{j}}{F_{j}}
$$

where $D_{j}$ is the release rate of the dosed marker $\left(\mathrm{C}_{32}\right.$, $\mathrm{C}_{36}$ and $\mathrm{Cr}$ ) by $\mathrm{CRC}$ (mg/day) and $F_{j}$ is the concentration $(\mathrm{mg} / \mathrm{kg} \mathrm{DM})$ of marker in faeces.

Digestibility was calculated as:

$$
\text { Digestibility }=\left(1-\frac{C_{i}}{C_{f}}\right)
$$

where $C_{i}$ and $C_{f}$ are the respective concentrations $(\mathrm{g} / \mathrm{kg} \mathrm{DM})$ of AIA in meadow hay and faeces.

\section{Statistical analysis}

Statistical analysis were carried out using the JMP program (JMP 2000). Concentrations of markers in faeces were analysed using analysis of variance to test the effect of breed (Barrosã or Holstein-Friesian), grab-sampling hour $(08.00$ or $20.00 \mathrm{~h})$ and its interaction. The effect of markers on the estimation of digestibility (five levels: AIA, $\mathrm{C}_{31}$ with 1.0 or 0.913 faecal recovery, $C_{33}$ with 1.0 or 0.942 faecal recovery) and faecal output (three levels: $\mathrm{Cr}, \mathrm{C}_{32}$ or $\mathrm{C}_{36}$ ) was investigated. Intake estimates were analysed for a given set of release rates (manufacturer's or calculated release rate) to test the effect of methodology (measured intake, $\mathrm{Cr} / \mathrm{AIA}, \mathrm{C}_{31}: \mathrm{C}_{32}$ and $\mathrm{C}_{33}: \mathrm{C}_{32}$ ) by analysis of variance. For paired comparisons, the Student's $t$-test was used.

\section{RESULTS}

\section{Marker concentrations in feed and refusals}

Table 2 shows the average content of n-alkanes and acid insoluble ash (AIA) in the meadow hay supplied to the animals during the 7-day sampling period. Only the Barrosã cows left any refusals. The concentrations of $\mathrm{C}_{22}$ and $\mathrm{C}_{34}$ are not presented as they were added to samples at the beginning of the analysis as internal standards for GC analysis.

The odd-chain n-alkanes comprised the highest fraction representing 0.921 of the total alkane content. The individual alkanes present in the highest concentrations $\left(\mathrm{C}_{29}\right.$ and $\mathrm{C}_{31}, 104.2$ and $134.7 \mathrm{mg} / \mathrm{kg}$ DM, respectively), made up 0.764 of the total oddchain n-alkanes.

The hydrocarbons $\mathrm{C}_{31}$ and $\mathrm{C}_{33}$, with chain lengths adjacent to the dosed synthetic n-alkane $\left(C_{32}\right)$, are usually used as markers to estimate intake, and had quite different concentrations, 134.7 and $27.3 \mathrm{mg} / \mathrm{kg}$ DM, respectively.
Table 2. Concentration of n-alkanes ( $m g / k g ~ D M)$ and acid insoluble ash (AIA; $\mathrm{g} / \mathrm{kg} D M$ ) in the meadow hay

\begin{tabular}{|c|c|c|c|c|}
\hline \multirow[b]{2}{*}{ n-alkanes } & \multicolumn{2}{|c|}{ Meadow hay } & \multicolumn{2}{|c|}{ Refusals } \\
\hline & Mean & S.E.M. & Mean & S.E.M. \\
\hline $\mathrm{C}_{23}$ & $4 \cdot 2$ & $0 \cdot 16$ & $9 \cdot 6$ & 0.43 \\
\hline $\mathrm{C}_{24}$ & $1 \cdot 5$ & 0.04 & $2 \cdot 2$ & $0 \cdot 06$ \\
\hline $\mathrm{C}_{25}$ & $13 \cdot 6$ & $0 \cdot 32$ & $25 \cdot 6$ & 0.83 \\
\hline $\mathrm{C}_{26}$ & $3 \cdot 1$ & 0.06 & $4 \cdot 6$ & $0 \cdot 12$ \\
\hline $\mathrm{C}_{27}$ & $26 \cdot 4$ & 0.68 & $49 \cdot 2$ & 1.99 \\
\hline $\mathrm{C}_{28}$ & $7 \cdot 1$ & $0 \cdot 24$ & $11 \cdot 0$ & $0 \cdot 37$ \\
\hline $\mathrm{C}_{29}$ & $104 \cdot 2$ & 3.76 & $151 \cdot 1$ & $6 \cdot 02$ \\
\hline $\mathrm{C}_{30}$ & $8 \cdot 4$ & $0 \cdot 31$ & $12 \cdot 2$ & 0.46 \\
\hline $\mathrm{C}_{31}$ & $134 \cdot 7$ & $6 \cdot 90$ & $181 \cdot 3$ & $6 \cdot 10$ \\
\hline $\mathrm{C}_{32}$ & $4 \cdot 3$ & $0 \cdot 18$ & $7 \cdot 3$ & $0 \cdot 36$ \\
\hline $\mathrm{C}_{33}$ & $27 \cdot 3$ & $1 \cdot 26$ & $36 \cdot 3$ & $1 \cdot 20$ \\
\hline $\mathrm{C}_{35}$ & $2 \cdot 4$ & 0.07 & $3 \cdot 6$ & $0 \cdot 12$ \\
\hline $\mathrm{C}_{36}$ & $2 \cdot 3$ & 0.05 & $2 \cdot 8$ & $0 \cdot 26$ \\
\hline Total odd-chain & $312 \cdot 8$ & $12 \cdot 32$ & $456 \cdot 8$ & $15 \cdot 64$ \\
\hline Total & $339 \cdot 5$ & $13 \cdot 04$ & $496 \cdot 9$ & $16 \cdot 67$ \\
\hline AIA & $23 \cdot 4$ & 0.55 & $32 \cdot 8$ & 0.96 \\
\hline
\end{tabular}
and in the refused feed

S.E.M. standard error of mean.

\section{Marker concentrations in faeces}

As expected, cow breed had a significant effect on the faecal concentrations of $\mathrm{C}_{32}(P<0.001), \mathrm{C}_{36}(P<$ $0.001)$ and $\mathrm{Cr}(P<0.001)$ (Table 3$)$, with the breed of higher body size and intake (Holstein-Friesian) showing lower concentrations of the dosed markers $\left(\mathrm{C}_{32}, \mathrm{C}_{36}\right.$ and $\left.\mathrm{Cr}\right)$ due to the higher faecal output. There was no significant breed effect on the faecal concentrations of the natural alkane $\mathrm{C}_{31}$ and a small but significant $(P<0.05)$ effect on $\mathrm{C}_{33}$ faecal concentration. Cow breed also significantly affected the concentration of AIA in faeces $(P<0.001)$.

The grab sampling hour $(08.00$ or $20.00 \mathrm{~h})$ had no significant effect on faecal concentration for any of the markers (Table 3).

\section{$C R C$ release rates}

The additional experiment performed in order to calculate the release rate of markers from the CRC showed that the linear release of the active core of chromium or of alkanes commenced soon after their insertion in the rumen, with no suggestion of a lag period (Fig. 1). The release rate was very similar between devices and the fitted regressions describing this linear phase did not differ significantly between animals. The linear release rates for the alkane CRC ranged from 1.944 to $1.982 \mathrm{~mm} /$ day $(\mathrm{CV}=0.97 \%)$ and from 1.442 to $1.459 \mathrm{~mm} /$ day $(\mathrm{CV}=0.66 \%)$ for the $\mathrm{Cr}_{2} \mathrm{O}_{3} \mathrm{CRC}$. Accordingly, the fitted regressions 
Table 3. Faecal concentration ( $m g / k g D M)$ of markers used to estimate intake

\begin{tabular}{|c|c|c|c|c|c|c|}
\hline \multirow[b]{3}{*}{ Marker } & \multicolumn{2}{|c|}{ Breed } & \multirow[b]{3}{*}{ S.E.M. } & \multirow[b]{3}{*}{ D.F. } & \multirow{2}{*}{\multicolumn{2}{|c|}{ Effect }} \\
\hline & & Holstein- & & & & \\
\hline & Barrosã & Friesian & & & Breed & Hour \\
\hline $\mathrm{C}_{31}$ & 299 & 313 & $6 \cdot 90$ & 108 & NS & NS \\
\hline $\mathrm{C}_{32}$ & 119 & 98 & $2 \cdot 21$ & 108 & $* * *$ & NS \\
\hline $\mathrm{C}_{33}$ & 63 & 66 & $1 \cdot 20$ & 108 & $*$ & NS \\
\hline $\mathrm{C}_{36}$ & 111 & 93 & 2.08 & 108 & $* * *$ & NS \\
\hline $\mathrm{C}_{\mathrm{r}}$ & 417 & 331 & 6.93 & 108 & $* * *$ & NS \\
\hline $\mathrm{AIA}^{\mathrm{a}}$ & 55 & 60 & 0.55 & 108 & $* * *$ & NS \\
\hline
\end{tabular}

a $\mathrm{g} / \mathrm{kg} \mathrm{DM}$.

S.E.M. standard error of mean. D.F.: degrees of freedom of the error term. NS, not significant; $* P<0.05 ; * * * P<0.001$.
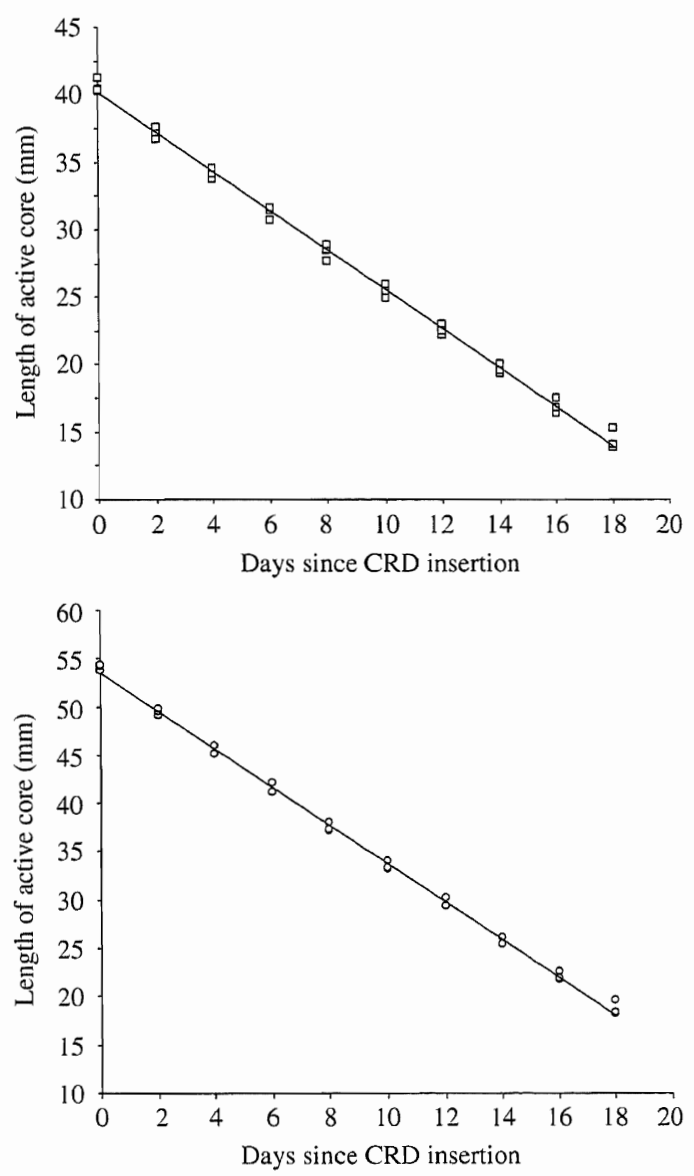

Fig. 1. Release of the active core from $\mathrm{Cr}_{2} \mathrm{O}_{3}(\square)$ and alkane (O) controlled-release capsules inserted into the rumen of 3 fistulated cows. The solid line is the common regression line, for which the slope is $-1.453 \mathrm{~mm} /$ day and $-1.964 \mathrm{~mm} /$ day, respectively.
Table 4. Mean estimated dry matter digestibility $(\mathrm{g} / \mathrm{kg}$ $D M$ ) of the meadow hay measured by the $A I A, C_{31}$ and $C_{33}$ markers

\begin{tabular}{lcccccccc}
\hline Breed & AlA $^{\mathrm{a}}$ & $\mathrm{C}_{31}{ }^{\mathrm{a}}$ & $\mathrm{C}_{31}{ }^{\mathrm{b}}$ & $\mathrm{C}_{33}{ }^{\mathrm{a}}$ & $\mathrm{C}_{33}{ }^{\mathrm{c}}$ & S.E.M. & D.F. & $F$ \\
\hline $\begin{array}{l}\text { Barrosã } \\
\text { Holstein- } \\
\text { Friesian }\end{array}$ & 584 & 557 & 596 & 576 & 601 & $18 \cdot 23$ & 15 & NS \\
\hline \hline
\end{tabular}

a Assuming a faecal recovery of $1 \cdot 0$.

${ }^{b}$ Assuming a faecal recovery of 0.913 (mean of data from Dove \& Oliván (1998) and Dove et al. (2002)).

c Assuming a faecal recovery of 0.942 (mean of data from Dove \& Oliván (1998) and Dove et al. (2002)).

S.E.M. standard error of mean. D.F.: degrees of freedom of the error term. NS, not significant.

shown in Fig. 1 are the overall regressions, the slope of which indicated a mean release rate of $1.964 \pm 0.017 \mathrm{~mm} /$ day for the alkane CRC and $1.453 \pm 0.016 \mathrm{~mm} /$ day for the $\mathrm{Cr}_{2} \mathrm{O}_{3}$ CRC. This linear release rate, coupled with the chromium and alkane contents/mm active core, indicated by the manufacturer, resulted in alkane and chromium release rates of $278.3 \mathrm{mg} \mathrm{C}_{32} /$ day, $294.3 \mathrm{mg} \mathrm{C}_{36} /$ day and $1003 \mathrm{mg}$ $\mathrm{Cr} /$ day. The corresponding release rates supplied by the manufacturer were $317 \cdot 2,335.4$ and $978.4 \mathrm{mg} /$ day respectively.

\section{Digestibility and faecal output estimates}

Table 4 shows the mean values of meadow hay digestibility $\left(\mathrm{g} / \mathrm{kg}\right.$ DM) estimated by AIA, $\mathrm{C}_{31}$ and $\mathrm{C}_{33}$ markers, assuming a faecal recovery of 1.0 for AIA (Block et al. 1981), 0.913 for $C_{31}$ (Dove \& Oliván 1998; Dove et al. 2002) and 0.942 for $C_{33}$ (Dove \& Oliván 1998; Dove et al. 2002). In both breeds, the meadow hay digestibility did not differ significantly between markers. There was no effect of marker either on estimated digestibility when a faecal recovery of 1.0 was applied to all markers. The mean values of faecal output ( $\mathrm{kg} \mathrm{DM} /$ day) estimated by $\mathrm{C}_{32}, \mathrm{C}_{36}$ and $\mathrm{Cr}$ markers are presented in Table 5. Although $\mathrm{C}_{32}$ marker is normally utilized as an intake marker when CRC are used, it can also be used as a faecal output marker (Eqn 3). The utilization of the CRC release rates indicated by the manufacturer led to $\mathrm{C}_{32}$-based faecal output estimates in Barrosã and Holstein-Friesian cows which were 11.3 and $10.6 \%$ higher, respectively, than $\mathrm{Cr}$-based estimates, though not significantly different from them. In the same way, the use of $\mathrm{C}_{36}$ (long-chain alkane with high faecal recovery, used generally as external marker for estimating faecal output) gave values of faecal output 23.6 and $21.7 \%$ higher than $\mathrm{Cr}$-based estimates, which were significantly higher than $\mathrm{Cr}$-based estimates for 
Table 5. Mean faecal output ( $\mathrm{kg}$ DM/day) estimated by the $C_{32}, C_{36}$ and $\mathrm{Cr}$ markers

\begin{tabular}{|c|c|c|c|c|c|c|c|c|}
\hline Breed & $\mathrm{Cr}^{\mathrm{a}}$ & $\mathrm{C}_{32}{ }^{\mathrm{b}}$ & $\mathrm{C}_{36}{ }^{\mathrm{c}}$ & S.E.M. & D.F. & F & Diff. $^{\mathrm{d}}$ & Diff.e \\
\hline \multicolumn{9}{|l|}{ Barrosã } \\
\hline Manufacturer release rate & $2 \cdot 36^{\mathrm{a}}$ & $2 \cdot 66^{\mathrm{a}}$ & $3 \cdot 09^{\mathrm{a}}$ & $0 \cdot 100$ & 9 & $* *$ & $+11 \cdot 3$ & $+23 \cdot 6$ \\
\hline Calculated release rate & $2 \cdot 42^{\mathrm{a}}$ & $2 \cdot 36^{\mathrm{a}}$ & $2 \cdot 73^{\mathrm{b}}$ & 0.092 & 9 & * & $-2 \cdot 5$ & $+11 \cdot 4$ \\
\hline \multicolumn{9}{|l|}{ Holstein-Friesian } \\
\hline Manufacturer release rate & $3 \cdot 03^{\mathrm{a}}$ & $3 \cdot 39^{\mathrm{a}}$ & $3.87^{\mathrm{a}}$ & $0 \cdot 317$ & 9 & NS & $+10 \cdot 6$ & $+21 \cdot 7$ \\
\hline Calculated release rate & $3 \cdot 11^{\mathrm{a}}$ & $3 \cdot 02^{\mathrm{a}}$ & $3 \cdot 42^{\mathrm{a}}$ & 0.294 & 9 & NS & $-3 \cdot 0$ & $+9 \cdot 1$ \\
\hline
\end{tabular}

a Assuming a faecal recovery of $1 \cdot 0$ (Dove et al. 2002).

${ }^{b}$ Assuming a faecal recovery of 0.928 (mean faecal recovery of that obtained by Dove \& Oliván (1998) and Dove et al. (2002)).

c Assuming a faecal recovery of 0.985 (mean faecal recovery of that obtained by Dove \& Oliván (1998) and Dove et al. (2002)).

${ }^{\mathrm{d}}$ Diff. $=\left(\mathrm{C}_{32}-\mathrm{Cr}\right) / \mathrm{C}_{32} \times 100$.

e Diff. $=\left(\mathrm{C}_{36}-\mathrm{Cr}\right) / \mathrm{C}_{36} \times 100$.

S.E.M. standard error of mean.

D.F.: degrees of freedom of the error term. NS, not significant; ${ }^{*} P<0.05 ;{ }^{* *} P<0.01$.

For a given breed, values in the same column with different letters are significantly different $(P<0.05)$.

Table 6. Mean values ( $\mathrm{kg} D M /$ day) of measured intake and estimated intake, using the release rate indicated by the manufacturer or the calculated release rate, for $C_{31}: C_{32}$ and $C_{33}: C_{32}$ alkane pairs and the $C r / A I A$ procedure

\begin{tabular}{|c|c|c|c|c|c|c|c|c|c|c|}
\hline \multicolumn{6}{|c|}{ Barrosã } & \multicolumn{5}{|c|}{ Holstein-Friesian } \\
\hline Intake & Mean & S.E.M. & Min. & Max. & Diff: $^{1}$ & Mean & S.E.M. & Min. & Max. & Diff. $^{1}$ \\
\hline Measured & $5 \cdot 64^{\mathrm{a}}$ & $0 \cdot 200$ & $5 \cdot 07$ & 5.94 & & $7 \cdot 76^{\mathrm{a}}$ & $0 \cdot 736$ & $5 \cdot 77$ & $8 \cdot 87$ & \\
\hline \multicolumn{11}{|c|}{ Estimated using the manufacturer release rate } \\
\hline $\mathrm{C}_{31}: \mathrm{C}_{32}$ & $6 \cdot 59_{b}$ & $0 \cdot 362$ & $5 \cdot 73$ & $7 \cdot 26$ & +0.95 & $8 \cdot 51^{\mathrm{a}}$ & 0.709 & $6 \cdot 47$ & $9 \cdot 76$ & +0.75 \\
\hline $\mathrm{C}_{33}: \mathrm{C}_{32}$ & $6 \cdot 90_{b}$ & $0 \cdot 297$ & $6 \cdot 15$ & $7 \cdot 39$ & $+1 \cdot 26$ & $8.95^{\mathrm{a}}$ & 0.763 & $6 \cdot 80$ & $10 \cdot 34$ & $+1 \cdot 19$ \\
\hline $\mathrm{Cr} / \mathrm{AIA}$ & $5 \cdot 66^{\mathrm{a}}$ & $0 \cdot 164$ & $5 \cdot 40$ & $6 \cdot 12$ & +0.02 & $7 \cdot 72^{\mathrm{a}}$ & $0 \cdot 774$ & $5 \cdot 80$ & $9 \cdot 13$ & -0.04 \\
\hline \multicolumn{11}{|c|}{ Estimated using the calculated release rate } \\
\hline $\mathrm{C}_{31}: \mathrm{C}_{32}$ & $5 \cdot 78^{a}$ & $0 \cdot 318$ & $5 \cdot 03$ & $6 \cdot 37$ & $+0 \cdot 14$ & $7 \cdot 47^{\mathrm{a}}$ & 0.622 & 5.68 & $8 \cdot 56$ & $-0 \cdot 29$ \\
\hline $\mathrm{C}_{33}: \mathrm{C}_{32}$ & $6 \cdot 06^{\mathrm{a}}$ & $0 \cdot 261$ & $5 \cdot 40$ & $6 \cdot 48$ & $+0 \cdot 42$ & $7 \cdot 85^{\mathrm{a}}$ & 0.670 & 5.96 & $9 \cdot 07$ & +0.09 \\
\hline $\mathrm{Cr} / \mathrm{AIA}$ & $5 \cdot 81^{\mathrm{a}}$ & $0 \cdot 169$ & $5 \cdot 53$ & $6 \cdot 27$ & $+0 \cdot 17$ & $7 \cdot 91^{\mathrm{a}}$ & 0.794 & $5 \cdot 94$ & $9 \cdot 36$ & +0.15 \\
\hline
\end{tabular}

S.E.M. standard error of mean.

${ }^{1}$ Diff. = estimated - actual.

For a given set of release rates, values in the same column with different letters are significantly different $(P<0 \cdot 05)$.

both breeds. When the CRRs were used, differences between $\mathrm{C}_{32}$ and $\mathrm{Cr}$ and $\mathrm{C}_{36}$ and $\mathrm{Cr}$ faecal outputs decreased to -2.5 and $11.4 \%$ for the Barrosã breed and -3.0 and $9 \cdot 1 \%$ for the Holstein-Friesian breed, with none of these differences being statistically significant.

\section{Real and estimated intakes}

Using the release rate indicated by the manufacturer the intake estimates for the Holstein-Friesian cows (Table 6), based on $\mathrm{C}_{31}: \mathrm{C}_{32}\left(8.51 \mathrm{~kg} \mathrm{DM} /\right.$ day), $\mathrm{C}_{33}: \mathrm{C}_{32}$ $(8.95 \mathrm{~kg} \mathrm{DM} /$ day) were 10 and $15 \%$ higher, respectively, than measured intake but did not differ significantly from it. Intake estimated using the Cr/AIA procedure $(7.72 \mathrm{~kg} \mathrm{DM} /$ day) did not differ from the measured intake ( $7.76 \mathrm{~kg} \mathrm{DM} /$ day). In contrast, in Barrosã cows the intake estimates using n-alkane pairs were both significantly higher $(P<0.05)$ from those obtained by the Cr/AIA procedure $(5.66 \mathrm{~kg}$ $\mathrm{DM} /$ day) and from the measured intake $(5.64 \mathrm{~kg}$ $\mathrm{DM} /$ day).

Using the CRRs (Table 6), the estimated intakes obtained by the three procedures did not differ significantly from the actual intake.

Table 7 shows the mean intake estimates in both breeds at each time of faecal sampling $(08.00$ and $20.00 \mathrm{~h}$ ) using the MRRs or the CRRs. As expected, the intake estimates obtained for the different sampling periods did not differ, as the sampling time did not have a significant effect on the faecal concentration of markers (Table 3 ). 
Table 7. Mean values (kg DM/day) of estimated intake for both breeds (Barrosã and Holstein-Friesian), using the release rate indicated by the manufacturer and the calculated release rate, for each hour of sampling

\begin{tabular}{|c|c|c|c|c|c|c|c|c|}
\hline \multirow[b]{4}{*}{ Intake } & \multicolumn{8}{|c|}{ Breed } \\
\hline & \multicolumn{4}{|c|}{ Barrosã } & \multicolumn{4}{|c|}{ Holstein-Friesian } \\
\hline & \multicolumn{2}{|c|}{ Manufacturer's rate } & \multicolumn{2}{|c|}{ Calculated rate } & \multicolumn{2}{|c|}{ Manufacturer's rate } & \multicolumn{2}{|c|}{ Calculated rate } \\
\hline & Mean & S.E.M. & Mean & S.E.M. & Mean & S.E.M. & Mean & S.E.M. \\
\hline \multicolumn{9}{|l|}{$\mathrm{C}_{31}: \mathrm{C}_{32}$} \\
\hline $08.00 \mathrm{~h}$ & $6 \cdot 56^{\mathrm{a}}$ & 0.400 & $5 \cdot 76^{a}$ & $0 \cdot 351$ & $8 \cdot 64^{\mathrm{a}}$ & 0.738 & $7 \cdot 58^{a}$ & 0.647 \\
\hline $20.00 \mathrm{~h}$ & $6 \cdot 62^{\mathrm{a}}$ & 0.332 & $5 \cdot 81^{\mathrm{a}}$ & $0 \cdot 291$ & $8 \cdot 39^{a}$ & $0 \cdot 702$ & $7 \cdot 36^{\mathrm{a}}$ & 0.616 \\
\hline $08.00+20.00 h$ & $6 \cdot 59^{a}$ & 0.362 & $5 \cdot 78^{a}$ & $0 \cdot 318$ & $8 \cdot 51^{\mathrm{a}}$ & $0 \cdot 709$ & $7 \cdot 47^{a}$ & 0.622 \\
\hline \multicolumn{9}{|l|}{$\mathrm{C}_{33}: \mathrm{C}_{32}$} \\
\hline $08.00 \mathrm{~h}$ & $6 \cdot 89^{a}$ & $0 \cdot 329$ & $6 \cdot 05^{a}$ & $0 \cdot 289$ & $9 \cdot 05^{\mathrm{a}}$ & 0.782 & $7 \cdot 94^{\mathrm{a}}$ & 0.686 \\
\hline $20.00 \mathrm{~h}$ & $6 \cdot 92^{\mathrm{a}}$ & 0.269 & $6 \cdot 07^{a}$ & $0 \cdot 236$ & $8 \cdot 85^{\mathrm{a}}$ & 0.754 & $7 \cdot 77^{\mathrm{a}}$ & 0.661 \\
\hline $08.00+20.00 \mathrm{~h}$ & $6 \cdot 90^{\mathrm{a}}$ & 0.297 & $6 \cdot 06^{a}$ & $0 \cdot 261$ & $8 \cdot 95^{\mathrm{a}}$ & 0.763 & $7 \cdot 85^{\mathrm{a}}$ & 0.670 \\
\hline \multicolumn{9}{|l|}{ Cr/AIA } \\
\hline $08.00 \mathrm{~h}$ & $5 \cdot 63^{a}$ & $0 \cdot 165$ & $5 \cdot 77^{\mathrm{a}}$ & $0 \cdot 169$ & $7 \cdot 53^{\mathrm{a}}$ & 0.747 & $7 \cdot 72^{\mathrm{a}}$ & 0.766 \\
\hline $20.00 \mathrm{~h}$ & $5 \cdot 70^{\mathrm{a}}$ & $0 \cdot 169$ & $5 \cdot 84^{\mathrm{a}}$ & 0.173 & $7 \cdot 92^{\mathrm{a}}$ & 0.804 & $8 \cdot 12^{\mathrm{a}}$ & 0.824 \\
\hline $08.00+20.00 \mathrm{~h}$ & $5 \cdot 66^{\mathrm{a}}$ & 0.165 & $5 \cdot 81^{\mathrm{a}}$ & $0 \cdot 169$ & $7 \cdot 72^{\mathrm{a}}$ & 0.774 & $7 \cdot 91^{\mathrm{a}}$ & $0 \cdot 794$ \\
\hline
\end{tabular}

S.E.M. standard error of mean.

Values in the same column for each method with different letters are significantly different $(P<0 \cdot 05)$.

\section{DISCUSSION}

The average odd-chain $\mathrm{n}$-alkane concentration found in the meadow hay is similar to the values reported by Mayes et al. (1995). These authors suggest that over $90 \%$ of the n-alkanes measured in plants possess an odd number of carbon atoms. Similarly, $\mathrm{C}_{29}$ and $\mathrm{C}_{31}$ are also reported as the predominant hydrocarbons of the odd-chains (Dove \& Mayes 1991, 1996; Oliván \& Osoro 1997).

The mean concentration of $\mathrm{C}_{33}$ in the meadow hay was less than $50 \mathrm{mg} / \mathrm{kg} \mathrm{DM}$, the content considered by Laredo et al. (1991) to be the minimum concentration that any n-alkane must have to be used as a marker. However, this minimum recommended value will depend on the analytical precision of laboratory procedures (Laredo et al. 1991). In this study, the high precision of analytical results for $\mathrm{C}_{33}$, estimated as the relative standard deviation (R.S.D.) of replicates, both in meadow hay (R.S.D. $=0.97)$ and faeces (R.S.D. $=3 \cdot 25$ ) led to the inclusion of $\mathrm{C}_{33}$ as a marker for intake estimation.

The AIA content of the meadow hay is within the range of values reported by Sunvold \& Cochran (1991) when studying alfalfa (3 g AIA $/ \mathrm{kg} \mathrm{DM}$ ), bromegrass (21 g AIA $/ \mathrm{kg} \mathrm{DM}$ ) and prairie hay (45 g AIA/kg DM). Van Keulen \& Young (1977) consider that the success of AIA utilization as a marker is limited, particularly in feeds with low AIA concentrations, because of the magnitude of errors in their analytical determination. Thonney et al. (1985) suggest that $7.5 \mathrm{~g} \mathrm{AIA} / \mathrm{kg} \mathrm{DM}$ is sufficient for obtaining precise estimates of digestibility. The mean concentration of AIA in the meadow hay $(23.4 \mathrm{~g}$ AIA/kg DM) used in our study was thus considered sufficient for the utilization of AIA as a marker.

Our results support the suggestion by Dove et al. (2002) that a period of 7 days after dosing the CRC is appropriate to provide a constant faecal concentration of $\mathrm{C}_{32}$, which, after this time, did not differ between days.

One of the main criteria for faecal marker use is that the daily faecal samples must be representative of total faeces, with respect to faecal marker concentrations, in order to obtain accurate estimates of intake. The utilization of controlled-release capsules aims to overcome this problem. For intake estimates, total faeces would clearly provide the most representative samples of faeces, but under field conditions, grab sampling is required. The present results indicated no significant time effects between grab-sampling times, or at least, that the frequency of collection did not allow observation of such a phenomenon. Similar results were obtained by Brandyberry et al. (1991) and Piltz et al. (1998) using $\mathrm{Cr}_{2} \mathrm{O}_{3}$ CRCs and Berry et al. (2000) and Dove et al. (2002) using n-alkane CRCs. Our results thus confirm those of Dove et al. (2002) in showing that the use of intra-ruminal devices reduces the cyclic temporal variation in faecal marker concentration that can occur with other ways of dosing such as once- or twice-daily dosing with gelatine or paper capsules (Dove et al. 2002). 
These results are also supported by the linear release of alkanes and chromium observed from the CRCs used to validate the release rate. However, the results we obtained are slightly different from those reported by Dove et al. (2002). These authors observed a lag period of 2 or 3 days after CRC administration in the disappearance of the active core, relating it to the time required for the $\mathrm{CRC}$ to equilibrate with the rumen environment. However no lag period is evident in our data (Fig. 1).

Additionally, there were no significant effects between grab sampling times on AIA faecal concentrations. The results of this study are in agreement with those reported by Van Keulen \& Young (1977) and Thonney et al. (1985), who found no variation in the daily faecal excretion pattern of AIA. The absence of diurnal variation in the faecal concentrations of all markers used is of extreme importance, allowing a reduction of the number of faecal samples that must be collected, thus minimizing the work required and the disturbance caused to the animals.

Mayes et al. (1986) suggested that to obtain accurate estimates of intake, the faecal recoveries of the two n-alkanes involved must be similar, so that the errors associated with incomplete recoveries cancel out in the equation used to estimate intake (see faecal ratio in Eqn 1 above). In this experiment, the discrepancy between the mean release rate of $\mathrm{C}_{32}$, indicated by the manufacturer $(317.2 \mathrm{mg} /$ day $)$ and the calculated release rate $(278.3 \mathrm{mg} /$ day $)$ produced an almost equivalent overestimation of herbage intake by either of the two n-alkane pairs (Table 6). Although the use of the n-alkane procedure does not involve separate calculations of faecal output and digestibility, this separation is useful when thinking of errors in the estimated intake, in order to identify whether they are coming from the faecal output or the digestibility estimates. The mean values of meadow hay digestibility (Table 4 ) estimated by AIA, $C_{31}$ and $\mathrm{C}_{33}$ markers did not differ significantly in either breed. These results suggest that in the alkane-based estimates of intake based on the manufacturer's documented release rates, the problem does not relate to the natural $n$-alkanes and their relationship with digestibility estimation, but rather to the dosed alkane markers.

In support of this suggestion, the mean values of faecal output estimated by $\mathrm{C}_{32}, \mathrm{C}_{36}$ and $\mathrm{Cr}$ markers show that the discrepancy between the MRRs and the CRRs produced different faecal output estimates (Table 5), which in the Barrosã breed reached significance and in the Holstein-Friesian breed were also high but were not significant. This indicates that the differences observed in intake estimation (Table 6) are related to the differences between the advised and the observed alkane release rates.

Brandyberry et al. (1991), Buntinx et al. (1992), Momont et al. (1994) and Santos \& Petit (1996) considered large deviations between observed and manufacturer-specified marker release rates to be one of the main limitations when $\mathrm{Cr}_{2} \mathrm{O}_{3} \mathrm{CRCs}$ are used. The results we have obtained suggest that the release rate of $\mathrm{Cr}_{2} \mathrm{O}_{3}$ indicated by the manufacturer was similar to that obtained in our conditions. However a significant deviation was observed between the alkane CRRs and those indicated by the manufacturer. It is therefore suggested that, where possible, release rates should be calculated within individual experiments.

As mentioned above, daily release rates of $\mathrm{Cr}, \mathrm{C}_{32}$ and $\mathrm{C}_{36}$ from the CRCs were estimated as the slope of the linear regression of payload length $v$. elapsed time, and were converted to $\mathrm{mg}$ of $\mathrm{Cr}_{2} \mathrm{O}_{3}, \mathrm{C}_{32}$ and $\mathrm{C}_{36}$ per day from the payload content in $\mathrm{Cr}$ and alkanes indicated by the manufacturer. Our calculated release rates thus rely on the assumption that the manufacturer's values for payload content are correct. We did not have spare CRCs to analyse in order to test this assumption, but the results of previous work suggest that variation in daily release rates of marker from such CRCs are related more to variations in linear release rate than variations in marker content in the payload. For example, in their study of the release of alkanes from sheep CRCs, Dove et al. (2002) found that linear release rates of seven devices varied by $12 \%$ between the highest and lowest observed values. By contrast, the analysis of the alkane content of three devices showed that the equivalent variation for payload content was much less $(2 \%$ for each of $\mathrm{C}_{28}$ and $\mathrm{C}_{32}$ alkanes). Later analyses of commercial alkane devices for cattle (H. Dove and R.E. Hendricksen, unpublished) have confirmed that most of the variation in daily release rate is associated with variation in linear release rate, rather than variation in alkane content.

Several previous studies (Vulich et al. 1991; Mayes et al. 1995; Dove \& Oliván 1998; Berry et al. 2000), showed that intake estimates based on the $\mathrm{C}_{32}: \mathrm{C}_{33}$ alkane pair are expected to be the most accurate, since this is the pair in which the difference in faecal recovery is likely to be minimal. Data presented indicate that, using either the release rate indicated by the manufacturer or the calculated release rate, intakes estimated using $\mathrm{C}_{31}: \mathrm{C}_{32}$ were not different from those estimated using the $\mathrm{C}_{32}: \mathrm{C}_{33}$ alkane pair, suggesting that the mean faecal recovery of the former pair of alkanes was also very similar.

\section{CONCLUSIONS}

Results indicate that $\mathrm{n}$-alkane or chromium release rates from intra-ruminal CRC are linear in cattle. The results presented in the present study confirm that accurate estimates of meadow hay intake by cattle can be obtained using the $\mathrm{Cr}_{2} \mathrm{O}_{3} / \mathrm{AIA}$ procedure when there is no deviation between advised and actual 
release rates. On the other hand, meadow hay intake estimates based on the n-alkane pairs $\left(\mathrm{C}_{31}: \mathrm{C}_{32}\right.$ and $\mathrm{C}_{33}: \mathrm{C}_{32}$ ) were initially over-estimated, due to the deviation of the actual release rate of $\mathrm{C}_{32}$ by the $\mathrm{CRC}$ from that indicated by the manufacturer. When release rates determined in our study were used, estimated and known intakes did not differ. It is suggested that in future experiments, validation studies of the mean release rate of markers by the $C R C$ should be conducted.

The authors would like to thank to Dr. M. Freer and Dr. E. Charmley for their helpful comments on an earlier version of the manuscript and to SERIDA administration for the facilities provided to perform the n-alkane analyses.

\section{REFERENCES}

Agricultural and Food Research Councll (AFRC) (1993). Technical Committee on Responses to Nutrients, Report no. 5. Nutritive Requirements of Ruminant Animals. Energy Nutrition Abstracts \& Review, Series B 60, 729-824.

Association of Official Analytical Chemists (AOAC) (1990). Official Methods of Analysis, 14th edn, 1. Washington DC, USA: AOAC.

Berry, N. R., Scheeder, M. R. L., Sutter, F., Krober, T.F. \& Kreuzer, M. (2000). The accuracy of intake estimation based on the use of alkane controlled-release capsules and faeces grab sampling in cows. Annales of Zootechnie 49, 3-13.

Block, E., Kilmer, L. H. \& Muller, L. D. (1981). Acid insoluble ash as a marker of digestibiiity for sheep fed corn plants or hay and for lactating dairy cattle fed hay ad libitum. Journal of Animal Science 52, 1164-1169.

Brandyberry, S. D., Cochran, R. C., Vanzant, E. S. \& Harmon, D. L. (1991). Technical note: Effectiveness of different methods of continuous marker administration for estimating fecal output. Journal of Animal Science 69, 4611-4616.

Buntinx, S. E., Pond, K. R., Fisher, D. S. \& Burns, J. C. (1992). Evaluation of the Captec chrome controlled-release device for the estimation of fecal output by grazing sheep. Journal of Animal Science 70, 2243-2249.

Burns, J. C., Pond, K. R. \& Fisher, D. S. (1994). Measurement of forage intake. In Forage Quality, Evaluation and Utilization (Eds G. C. Fahey Jr., M. Collins, D. R. Mertens \& L. E. Moser), pp. 494-532. Madison, WI: American Society of Agronomy, Inc., Crop Science Society of America, Inc., Soil Science Society of America, Inc.

Dove, H., Freer, M. \& Foot, J. Z. (2000). The nutrition of grazing ewes during pregnancy and lactation: a comparison of alkane-based and chromium/in vitro-based estimates of herbage intake. Australian Journal of Agricultural Research 51, 765-777.

Dove, H. \& MAYES, R. W. (1991). The use of plant wax alkanes as marker substances in studies of the nutrition of herbivores: a review. Australian Journal of Agricultural Research 42, 913-952.

Dove, H. \& MAyes, R. W. (1996). Plant wax components: a new approach to estimating intake and diet composition in herbivores. Journal of Nutrition 126, 13-26.

Dove, H., Mayes, R. W., LAmb, C. S. \& Ellis, K. J. (2002). Factors influencing the release rate of alkanes from an intra-ruminal, controlled-release device, and the resultant accuracy of intake estimation in sheep. Australian Journal of Agricultural Research 53, 681-696.
Dove, H. \& Olıván, M. (1998). Using synthetic or beeswax alkanes for estimating supplement intake in sheep. Animal Production in Australia 22, 189-192.

Fenton, T. W. \& Fenton, M. (1979). An improved procedure for the determination of chromic oxide in feed and feces. Canadian Journal of Animal Science 59, 631-634.

JMP (2000). User's Guide: Statistical Discovery Software (Version 4). Cary, NC: SAS Inst. Inc.

Laredo, M. A. Simpson, G. D., Minson, D. J. \& Orpin, C. G. (1991). The potential for using n-alkanes in tropical forages as a marker for the determination of dry matter intake by grazing ruminants. Journal of Agricultural Science, Cambridge 117, 355-361.

Luginbuhl, J. M., Pond, K. R., Burns, J. C. \& Fisher, D. S. (1994). Evaluation of the Captec controlled-release chromic oxide capsule for fecal output determination in sheep. Journal of Animal Science 72, 1375-1380.

Mayes, R. W., Dove, H., Chen, X.B. \& Guada, J.A. (1995). Advances in the use of faecal and urinary markers for measuring diet composition, herbage intake and nutrient utilisation in herbivores. In Recent Developments in the Nutrition of Herbivores, Proceedings of the IVth International Symposium on the Nutrition of Herbivores (Eds M. Journet, E. Grenet, M.-H. Farce, M. Thériez \& C. Demarquilly), pp. 381-406. Paris: INRA editions.

Mayes, R. W., Lamb, C. S. \& Colgrove, P. M. (1986). The use of dosed and herbage n-alkanes as markers for the determination of herbage intake. Journal of Agricultural Science, Cambridge 107, 161-170.

Momont, P. A., Pruitt, R. J., Emerick, R. J. \& Pritchard, R. H. (1994). Controlled-release chromic oxide and alkaline peroxide lignin marker methods. Journal of Range Management 47, 418-423.

Oliván, M. \& Osoro, K. (1994). Posibilidades de la técnica de los n-alcanos en la estimación de la ingestión, digestibilidad y composición de la dieta de rumiantes en pastoreo. In Proceedings of the "XXXIV Reunión Cientifica de la S.E.E.P.", pp. 391-396. Santander, Spain.

Oliván, M. \& Osoro, K. (1997). Utilización de la técnica de los n-alcanos en estudios de ingestión y selección de dieta de los rumiantes en pastoreo: Revisión. Información Técnica Económica Agraria 93A, 193-208.

Oliván, M. \& Osoro, K. (1999). Effect of temperature on alkane extraction from faeces and herbage. Journal of Agricultural Science, Cambridge 132, 305-312.

Parker, W. J., Morris, S. T., Garrick, D. J., Vincent, G. L. \& MCCutcheon, S. N. (1990). Intraruminal chromium controlled release capsules for measuring herbage intake in ruminants - a review. Proceedings of the New Zealand Society of Animal Production 50, 437-442. 
Piltz, J. W., Kaiser, A. G. \& Gogel, B. J. (1998). Prediction of faecal output using chromic oxide controlled release devices. Animal Production in Australia 22, 351.

Robertson, J. B. \& VAN Soest, P. J. (1981). The detergent system of analysis and its application to human foods. In The Analysis of Dietary Fiber (Eds W. P. T. James \& O. Theander), pp. 123-158. New York: Marcel Dekker.

Santos, G. T. \& Petrt, H. V. (1996). Prediction of total fecal output in sheep fed silage using the Captec chrome controlled-release capsule. Small Ruminant Research 20, 223-227.

Sunvold, G. D. \& Cochran, R. C. (1991). Technical note: Evaluation of acid detergent lignin, alkaline peroxide lignin, acid insoluble ash, and indigestible acid detergent fiber as internal markers for prediction of alfalfa, bromegrass, and prairie hay digestibility by beef steers. Journal of Animal Science 69, 4951-4955.

Thonney, M. L., Palhof, B. A., DeCarlo, M. R., Ross, D. A., Firth, N. L., Quias, R. L., Perosio, D. J., Duhaime, D. L. \& Nour, A. Y. M. (1985). Sources of variation of dry matter digestibility measured by the acid insoluble ash marker. Journal of Dairy Science 68, 661-668.

Van Keulen, J. \& Young, B. A. (1977). Evaluation of acidinsoluble ash as a natural marker in ruminant digestibility studies. Journal of Animal Science 44, 282-287.

VAN SOEST, P. J. (1994). Nutritional Ecology of the Ruminant, 2nd edn. Ithaca, New York: Comstock.

Vulich, S. A., O'Riordan, E. G. \& Hanrahan, J. P. (1991). Use of n-alkanes for the estimation of herbage intake in sheep: accuracy and precision of the estimates. Journal of Agricultural Science, Cambridge 116, 319-323. 